\title{
Beata Borowska-Beszta, „Etnografia stylu życia kultury dorosłych torunian z zaburzeniami rozwoju", Wyd. Naukowe Uniwersytetu Mikołaja Kopernika, Toruń 2013
}

Osoby niepełnosprawne stanowią jedną z grup będących obiektem zainteresowań andragogiki, zwykle zaliczanych do szerszej kategorii określanej mianem grupy defaworyzowanych. Zazwyczaj jednak andragodzy mają w takim przypadku na myśli niepełnosprawnych ruchowo lub sensorycznie, rzadko osoby z niepełnosprawnością intelektualną. Recenzowana pozycja poświęcona została właśnie dorosłym osobom niepełnosprawnym intelektualnie, uwzględniając również grunt andragogiczny.

Wydana publikacja jest rozprawą habilitacyjną, stanowiącą ukoronowanie dotychczasowej działalności naukowej dr Beaty Borowskiej-Beszty, wieloletniej pracowniczki Uniwersytetu Mikołaja Kopernika, znakomitej pedagog i andragog specjalnej. Autorka od początku lat 90. do 2008 roku pracowała jako instruktorka w warsztatach terapii zajęciowej, gdzie zdobyła bogate doświadczenie praktyczne. Opracowała również autorską, wdrożoną już, metodę terapii przez twórcze pisanie (MII - Metoda Intymności i Interakcyjności). Później rozpoczęła także badania nad zagadnieniami dotyczącymi życia, edukacji oraz terapii osób niepełnosprawnych intelektualnie, w których wykazywała nie tylko wysoką świadomość metodologiczną, ale także niezwykłą wrażliwość wobec badanego terenu. Świadczą o tym jej wcześniejsze publikacje zwarte, m.in. „Etnografia dla terapeutów (pedagogów specjalnych) - szkice metodologiczne” (2005), „Echa ekspresji. Kulturoterapia w andragogice specjalnej” (2008), „Wanda Szuman - pedagog i andragog specjalny - szkice do portretu” (red., 2009), „Niepełnosprawność w kontekstach kulturowych" (2012). 
Od początku autorka usytuowała się w obszarze badań jakościowych, a jej zainteresowania zamanifestowane zostały w wyborze strategii badawczej, jaką jest etnografia. Spojrzenie na osoby niepełnosprawne intelektualnie jako na grupę posiadającą własną kulturę, odmienną od kultury dominującej, jest niezwykle interesującą perspektywą, dającą badaczowi wiele możliwości interpretacji fenomenów pojawiających się w strefie jednej kultury i na styku obu tych kultur. Stąd też tytuł recenzowanej publikacji „Etnografia stylu życia kultury dorosłych torunian z zaburzeniami rozwoju", czytelny i wyraźnie zakreślający obszar eksploracji opisany w książce. Dziwić może jedynie osoby zupełnie nieobyte $z$ perspektywą antropologii kulturowej i kulturowego ujmowania życia człowieka i edukacji. Dlaczego jednak w tytule pojawia się określenie „zaburzenia rozwoju”? Otóż badaną przez autorkę grupę stanowiło 50 dorosłych osób zamieszkujących w Toruniu, u których występuje nie tylko niepełnosprawność intelektualna w stopniu lekkim, umiarkowanym lub znacznym, ale także zaburzenia sprzężone w postaci np. padaczki, mózgowego porażenia dziecięcego, schizofrenii, autyzmu, niedosłuchu czy słabowzroczności.

Na publikację składają się 4 rozdziały, ujęte w dwóch częściach: teoretycznej i badawczej. Część pierwsza, mająca charakter teoretyczny stanowi nie tyle przegląd literatury dotyczącej stylu życia, choć autorka przytacza ujęcia tego fenomenu m.in. u A. Adlera, M. Webera, A. L. Kroebera, ale trzon opracowania stanowi przegląd badań polskich i zagranicznych prowadzonych nad stylem życia, począwszy od przełomu wieku XIX i XX aż do początku wieku XXI. W części drugiej przedstawiła autorka założenia metodologiczne badań własnych, w których po dokonaniu charakterystyki głównych stanowisk metodologicznych, określa swoje stanowisko ontologiczne, epistemologiczne oraz metodologiczne, argumentując za wyborem etnografii. Dalsze dwa rozdziały części badawczej to deskryptywny opis dziedzin obrazu siebie, świata i stylu życia dorosłych torunian z zaburzeniami rozwoju, bogato ilustrowanymi fragmentami wywiadów oraz esej etnograficzny, stanowiący domknięcie przeprowadzonych wcześniej analiz i główne wnioski płynące z badań.

Po krótkim zakończeniu autorka zamieściła imponującą bibliografię, liczącą 463 pozycje w języku polskim i angielskim, odsyłające zainteresowanego czytelnika do tekstów poruszających problematykę niepełnosprawności, andragogiki czy metodologii. Na uwagę zasługuje fakt, że autorka biegle posługuje się językiem angielskim, co zaowocowało nie tylko przytoczeniem publikacji, głównie amerykańskich, do których warto zajrzeć, ale również jej 
własnymi przekładami definicji czy cytowanych fragmentów tekstów. Książka zawiera również angielskie streszczenie.

W aneksie znajdzie czytelnik nie tylko wzór kwestionariusza wywiadu, którym posłużyła się autorka, ale również formularz zgody na udział w badaniu. Nie zawsze jest to praktykowane, często badacze bazują na dobrowolnym udziale badanego, wyrażonym na podstawie zgody ustnej. Ze względu jednak na badaną grupę oraz skrupulatne przestrzeganie zasad etycznych obowiązujących w badaniach społecznych, autorka zadbała o zgodę pisemną.

$\mathrm{Na}$ osobną uwagę i szczególne podkreślenie zasługuje wprowadzenie, jakie autorka napisała, nazywając je autoetnograficznym. Z jednej strony wpisuje się w ten sposób w całości w etnograficzną konwencję badań, dającą badaczowi możliwość na wyrażenie również własnego głosu, a nie tylko na oddanie go samym osobom badanym. $Z$ drugiej strony wprowadzenie to, w których autorka dzieli się z czytelnikami często bardzo osobistymi doświadczeniami, pozwala lepiej zrozumieć jej perspektywę, dokonywane wybory naukowe i badawcze, jak też wyraźnie podkreśla grunt jakościowy, dystansując się tym samym od ujęć pozytywistycznych czy neopozytywistycznych, w których badacz ukrywa się za tekstem.

Walorem recenzowanej publikacji jest niewątpliwie fakt, że autorka wykazuje się doskonałą znajomością teoretycznych koncepcji i badawczych ujęć eksplorowanego przez nią zagadnienia. Odwołuje się do teorii antropologicznych i socjologicznych, w mniejszym stopniu do psychologicznych, które stanowią tło dla poruszanych dalej koncepcji i badań z zakresu pedagogiki i andragogiki specjalnej. Autorka dokonała wnikliwego przeglądu polskich i zagranicznych, głównie anglosaskich, badań dotyczących stylu życia osób niepełnosprawnych oraz kulturowego ujmowania niepełnosprawności, co z kolei stanowi podstawę teoretyczną dla analizowanych dalej badań własnych.

W pracy zawarte zostały również, co nie zdarza się często w polskiej literaturze pedagogicznej, refleksje własne autorki co do przebiegu badań, wskazanie na pojawiające się trudności, ale i ułatwienia ze strony ośrodków terapeutycznych dla osób niepełnosprawnych, gdzie badania były realizowane. Jest to oczywiście naturalna część badań etnograficznych, ale rzadkością jest, aby badacz aż tak dokładnie i szczerze relacjonował swój pobyt w terenie. Tym samym tworzy się fałszywe wrażenie, że badania przebiegały gładko i bezproblemowo, co nie jest do końca zgodne z rzeczywistością. Autorka burzy to poczucie komfortu u czytelnika, a jej relacje mają doniosłą wartość edukacyjną, w szczególności dla badaczy początkujących lub też tych, któ- 
rzy chcą zacząć swoją przygodę z badaniami jakościowymi, zwłaszcza strategią etnograficzną.

Wielokrotnie odwołuje się autorka do własnych doświadczeń badawczych, pokazując jednocześnie swoją drogę kształtowania się jej świadomości i umiejętności metodologicznych w obszarze etnografii. Na podkreślenie zasługuje konsekwencja, z jaką dokonywała kolejnych wyborów i realizowała projekty badawcze, pozyskując na nie zewnętrzne środki finansowe. Badania, których analizy zostały przedstawione w recenzowanej książce, również sfinansowane były z grantu MNISW.

Niezwykle istotną zaletą recenzowanej publikacji jest język, którym posługuje się autorka - przejrzysty, zrozumiały, konsekwentny. Tekst czyta się z dużą przyjemnością, nie ma takich miejsc, w których czytelnik miałby problemy ze zrozumieniem treści, nawet jeśli nie specjalizuje się w problematyce niepełnosprawności. Ponadto autorka podaje dużo dodatkowych informacji np. o badaczach i teoretykach, na których się powołuje, dotyczących ich życia, zainteresowań. Tłumaczy też w bardzo przystępny sposób określenie, którym się posługuje - „habilitacja”, a nie „rehabilitacja” dorosłych osób niepełnosprawnych.

Autorka poprowadziła swoje rozważania i analizy badań z punktu widzenia pedagogiki i andragogiki specjalnej, wielokrotnie odwołując się do znanych publikacji andragogicznych. W końcowej części książki przedstawia również rekomendacje własne, jakie sformułowała na bazie wyników swoich badań i wyciągniętych z nich wniosków. Część z tych rekomendacji dotyczy andragogów i zakreśla obszar działań, jakim andragogdzy niewątpliwie powinni się zająć. Są to działania w zakresie przygotowania, wdrożenia i rozwinięcia programów edukacji ustawicznej dla osób niepełnosprawnych intelektualnie. Autorka odnotowuje w tym obszarze szczególnie dotkliwe braki takiej oferty, co z jednej strony powoduje wykluczanie osób z niepełnosprawnością intelektualną i wrzucanie ich w edukacyjną pustkę. Z drugiej strony, powstałą niszę wypełniają media ze swoją ofertą, którą można różnie ocenić, jednakże z braku alternatywy stanowią obecnie dla osób niepełnosprawnych intelektualnie jedno z głównych źródeł edukacji i wzorców życiowych. Uważna analiza podawanych przez dr Beatę Borowską-Besztę rekomendacji otwiera przed andragogami szerokie pole nie tylko działań praktycznych, ale i nowych projektów badawczych, we współpracy z pedagogiami i andragogami specjalnymi oraz praktykami w obszarze niepełnosprawności intelektualnej. Jest to również inspiracja dla andragogów w kwestii szkoleń dla pracodawców, którzy nie mając tej świadomości, nie chcą lub też boją się zatrudniać osoby niepełnosprawne intelektualnie na otwartym 
rynku pracy. Niszcząco w tym zakresie działa również obowiązująca ideologia neoliberalizmu i akcentowanie wydajności. Analiza danych z badań przeprowadzonych przez autorkę koryguje często fałszywy obraz osób z niepełnosprawnością intelektualną, jaki posiadają pracodawcy, wskazując na pracę zawodową jako ważny obszar w życiu takich osób.

Reasumując, recenzowana publikacja z całą pewnością zasługuje na to, by zapoznali się z nią andragodzy, nawet jeśli ich badania i zainteresowania naukowe nie wiążą się z tematyką niepełnosprawności, zwłaszcza intelektualnej. Książka dr Beaty Borowskiej-Beszty stanowić może nie tylko inspirację dla dalszych działań andragogicznych i ich rozwoju, ale również stanowi wzorzec rzetelnie przeprowadzonych badań jakościowych.

Anna Frąckowiak 